\title{
Framing the Sustainable Energy Challenge and Implications for Solutions
}

\author{
Charlotte Jensen, Inge Røpke, Gary Goggins and \\ Frances Faby
}

Abstract Sustainable consumption policies often rely on ecological modernisation rationality, where the focus is usually on making current consumption patterns more sustainable in such a way that status quo (ideas about the quality of life and growth) is not challenged. As a result, sustainable energy policies tend to black box the demandside, often resulting in abstracting efficiency strategies from the social

C. Jensen $(\varangle)$. I. Røpke

Department of Planning, Aalborg University, Copenhagen, Denmark

e-mail: cjensen@plan.aau.dk

I. Røpke

e-mail: ir@plan.aau.dk

G. Goggins · F. Fahy

School of Geography and Archaeology and Ryan Institute,

National University of Ireland Galway, Galway, Ireland

e-mail: gary.goggins@nuigalway.ie

F. Fahy

e-mail: frances.fahy@nuigalway.ie

(C) The Author(s) 2019

F. Fahy et al. (eds.), Energy Demand Challenges in Europe, https://doi.org/10.1007/978-3-030-20339-9_2 
organisation within which the strategies and resulting solutions unfold. Rebound effects and other unintended consequences often happen as a result of this type of efficiency strategies. This chapter introduces alternative problem framings that may offer a way to mitigate rebound effects by addressing and challenging a wider set of socio-material, cultural and institutional aspects of energy demand.

Keywords Energy demand - Problem framings - Energy policy • Sustainable consumption · Transformation

\section{INTRODUCTION}

Over the past few decades, consumer-oriented environmental policies have proliferated as political and public interest and concern for environmental issues have increased significantly (Christensen et al. 2007). As a result, it is not uncommon that citizens as consumers are assigned responsibility for sustainable development. This in itself may not be a problem, but it is important to highlight how responsibility is assigned, in what way, and what it means for the type of development that emerges and is emphasised as a result. As sustainable consumption policies often rely on ecological modernisation rationality, these policies often centre on making current consumption patterns more sustainable in such a way that new business opportunities can emerge and 'quality' of life is not challenged (Sedlacko et al. 2014). As a result energy policies tend to focus on making existing behaviours more sustainable; a focus that often ends up abstracting efficiency strategies from the social organisation within which the strategies and resulting solutions unfold (Labanca and Bertoldi 2018).

In this chapter, we open with a discussion of the type of common energy problem framings that appear embedded in most consumeroriented (sustainable) energy policies, and what these problem framings imply for the type of results obtained. We then discuss alternative energy problem framings that may be beneficial to implement in consumeroriented (sustainable) energy policies. Approaches for example that might mitigate potential rebound effects or other unintended consequences that often are the result of the dominant types of efficiency strategies. We facilitate this discussion by introducing the ENERGISE Problem 
Framing Typology, that highlights different dimensions and aspects of the problem framings most commonly used ('technology-orientated' and 'individual behaviour-oriented') as well as of problem framings that are much less used ('everyday life oriented' and 'systems oriented'). The latter we argue can offer insights into how social, cultural and institutionalised aspects of energy consumption can be investigated and challenged as part of the efforts of reducing energy consumption levels.

\section{Common Energy Problem Framings}

It is widely acknowledged that environmental and climate change policies often build on dominant paradigms of economics and psychology. This means that the theories of change embedded in many policies pave the way for the assumption that climate change problems are a result of individual actions, which can be changed by addressing attitudes, behaviours and choice (Shove 2010). This is often operationalised in strategies that attempt to shift people's choices away from unsustainable or inefficient products towards more sustainable or efficient products, primarily through information and the promotion of (energy) efficient products (Spurling et al. 2013). As Labanca and Bertoldi (2018: 496) state, such strategies often assume that solutions can be 'surgically removed and replaced by other solutions, seamlessly entering the social tissue where they are installed, without causing any change but reduction in energy inputs'.

Although technological innovation can bring about significant efficiency potentials, these may only be realised if appropriate economic instruments are applied simultaneously, so that gains from efficiency strategies are not just directed towards other unsustainable areas (Christensen et al. 2007; Shove 2017). This means that if energy efficiency strategies are applied without addressing and potentially disrupting systems of interacting, unsustainable practices that generate high levels of energy demand, the energy demand problem is not addressed but potentially only shifted, instigating a possible rebound effect.

As Southerton and Welch (2018) highlight, required reductions in consumption-related emissions cannot be achieved through marginal lifestyle changes and technical efficiencies. While the environmental impact of economic outputs has been reduced in advanced economies, the relationship between growth in per capita income and growth in per 
capita GHG emissions continues. This finding is supported by Bjørn et al. (2018), who find that if levels in consumption-related demand are not lowered, technological development will not deliver the requirements to meet the climate goals set out in the Paris Agreement. Problem framings that understand energy use and consumption as a result of technological efficiency and incremental lifestyle (behaviour) changes thus have seemingly limited potential to achieve the needed fundamental changes in energy demand levels.

According to the ENERGISE typology of energy problem framings (Jensen et al. 2017), two main types of problem framings are often employed within current sustainable energy consumption initiatives (SECIs), technology-orientated or behaviour-orientated. Consequently, a majority of initiatives either take technological development or changes in individual behaviours as the main drivers of change.

What does this look like in practice? A typical example of a SECI underpinned by a technological problem framing would be if energy use related to, for example, heating is solely (or at least primarily) understood to be a matter of optimising heating systems. Optimisation could also include a focus on providing (technical) labelling for heating systems so that the 'consumer' can easily navigate between different settings in terms of energy efficiency. Such SECIs, however, do not explicitly challenge the extent and duration for which people heat their homes, nor would they fundamentally challenge any notions related to maximum or minimum temperatures. SECIs within this framing category would therefore not explicitly challenge what is understood to be appropriate levels of indoor comfort in different contexts and situations.

A general illustration of a SECI underpinned by a behaviour change type of problem framing might go a bit further than relying on energy efficiency labelling of products. Often this expanded approach puts emphasis on providing more information about why it is good for the consumer to choose an efficient heating system, or why the consumer should turn down their thermostat. Information provided may focus on monetary incentives or it may address ecological consequences of not choosing the most energy efficient option. It does however not challenge socially shared norms around heating, or what it means to feel 'comfortable'. 


\section{Alternative Energy Problem Framings}

As several researchers (e.g. Spurling et al. 2013; Southerton and Welch 2018; Genus et al. 2018) suggest, it may instead be beneficial to establish new problem framings that lead to altogether fundamentally different modes of governance and policies that disrupt unsustainable practices, or reconfigure links between practices. In this way, it is not energy consumption in itself that is targeted (and made efficient) but rather, it is what energy is for that is scrutinised and challenged (Shove and Walker 2014). Related energy problem framings pose altogether different questions about what needs to be changed, why and how. The resulting solution space(s) would be broader (and more complex) than for dominant energy problem framings, and would presuppose a reflexive mode of governance. According to the ENERGISE typology of energy problem framings, two types of alternative energy problem framings follow along these lines of rationale, however they are only rarely utilised in existing SECIs. One of these problem framings understands everyday life situations as being the central point of departure for change potentials, and another understands complex interactions between multiple actors, systems and practices as being the point of departure for potential change.

In contrast to the common energy problem framings discussed earlier, SECIs that seek to address heating related energy use, and which are underpinned by an everyday life situations problem framing, would approach energy use altogether differently. In these cases, the situations of everyday life that have an implication for the way, as well as the frequency and extent to which, people heat their homes would thus be the 'unit' of interventions. Here, SECIs might target routines and ideas related to how, why and when people heat their homes in different types of situations. This could be in terms of challenging ideas about norms and comfort that can vary across situations, for example when receiving guests. Solutions within this problem framing might include heating people instead of spaces, providing low-energy alternatives to space heating such as wearing more clothes, using blankets or rearranging furniture. In that way, SECIs underpinned by this problem framing may address understandings of comfort and material aspects of heating, and may employ a notion of sufficiency rather than efficiency (see Sahakian et al. 2019). 
In the context of SECIs that adopt a problem framing that presumes a broader interaction between multiple actors, systems and practices to be central to change, these initiatives would target energy use related to heating as a matter of challenging current ideas about comfort and routines related to heating homes. In addition, they would argue for (or ideally even enable) political and legislative changes in terms of how energy for heating is produced and distributed, so that consumers and communities benefit from a low-carbon transition. SECIs underpinned by this type of problem framing could also challenge norms and standards for increasingly bigger homes (increasing number of square meters per person), as the savings gained by efficient heating systems are often offset by houses getting increasingly bigger (Christensen et al. 2007). These SECIs target a wider range of actors, challenge existing ways of organising everyday life around more sustainable systems of production and consumption, as well as building community and institutional networks for sustainable transformation of buildings. Eco-communities often resemble such attempts, by socially and materially organising different ways for producing energy as well as spaces for sharing particular types of activities, sometimes resulting in smaller private homes, which enable people to engage in alternative heating practices.

\section{How Different Types of Problem Framings Generate Different Objectives, Targets and Outputs}

The four types of problem framings discussed above are summarised below in terms of implied objectives, methods of intervention, consumption areas targeted, types of outputs and types of change. The two first types of problem framings (Changes in Technology and Changes in Individuals Behaviours) belong to what we here describe as common energy policy problem framings. The last two types of problem framings (Changes in Everyday Life Situations and Changes in Complex Interactions) belong to what is in this chapter termed alternative energy problem framings. The typology categories and highlighted dimensions of change summarised below are based on a large-scale review of 1000+recent and current European SECIs (Jensen et al. 2017). ${ }^{1}$

\footnotetext{
${ }^{1}$ For an overview of SECIs classifications, please visit our database http://energise-project.eu/projects
} 


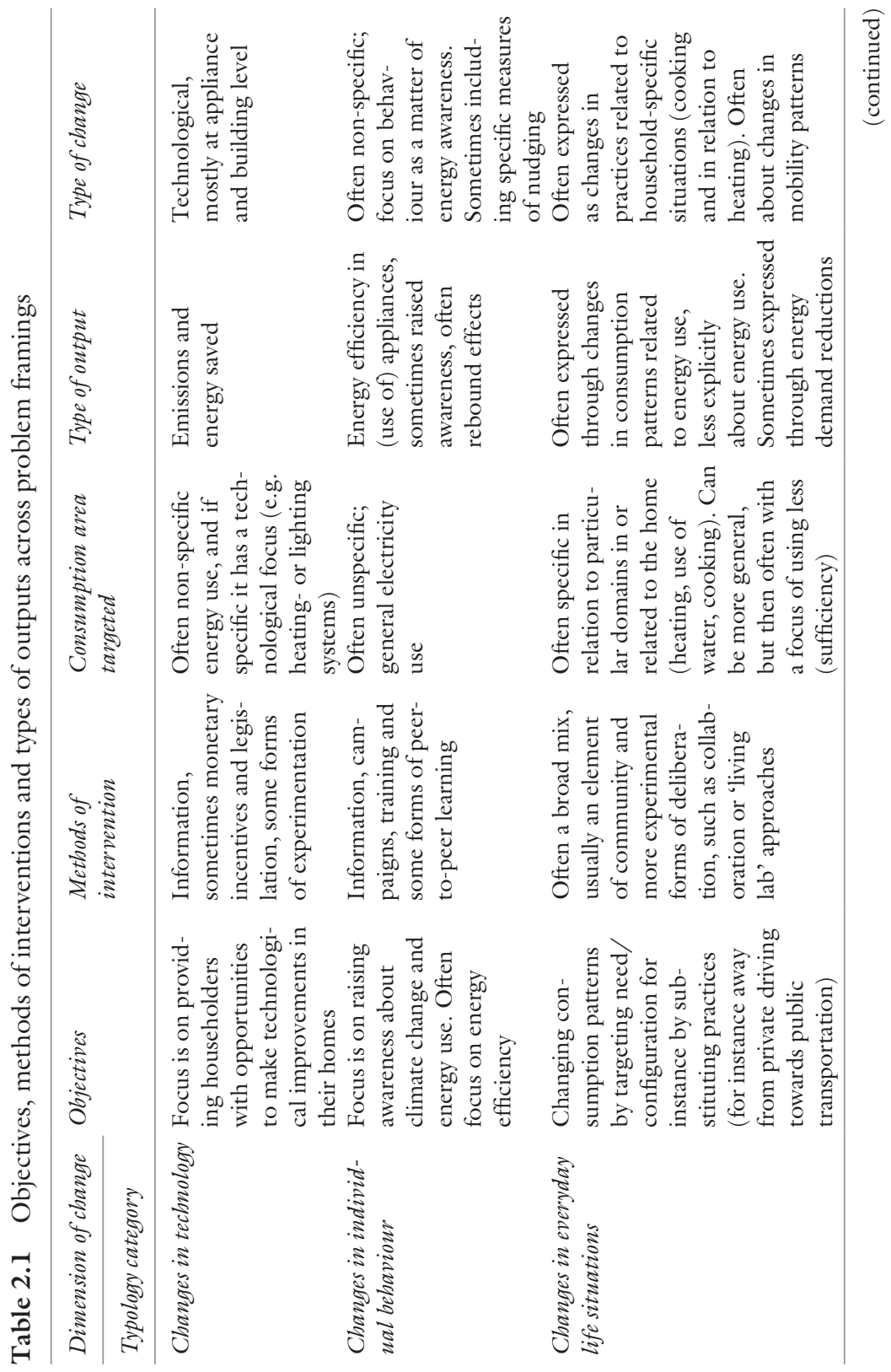




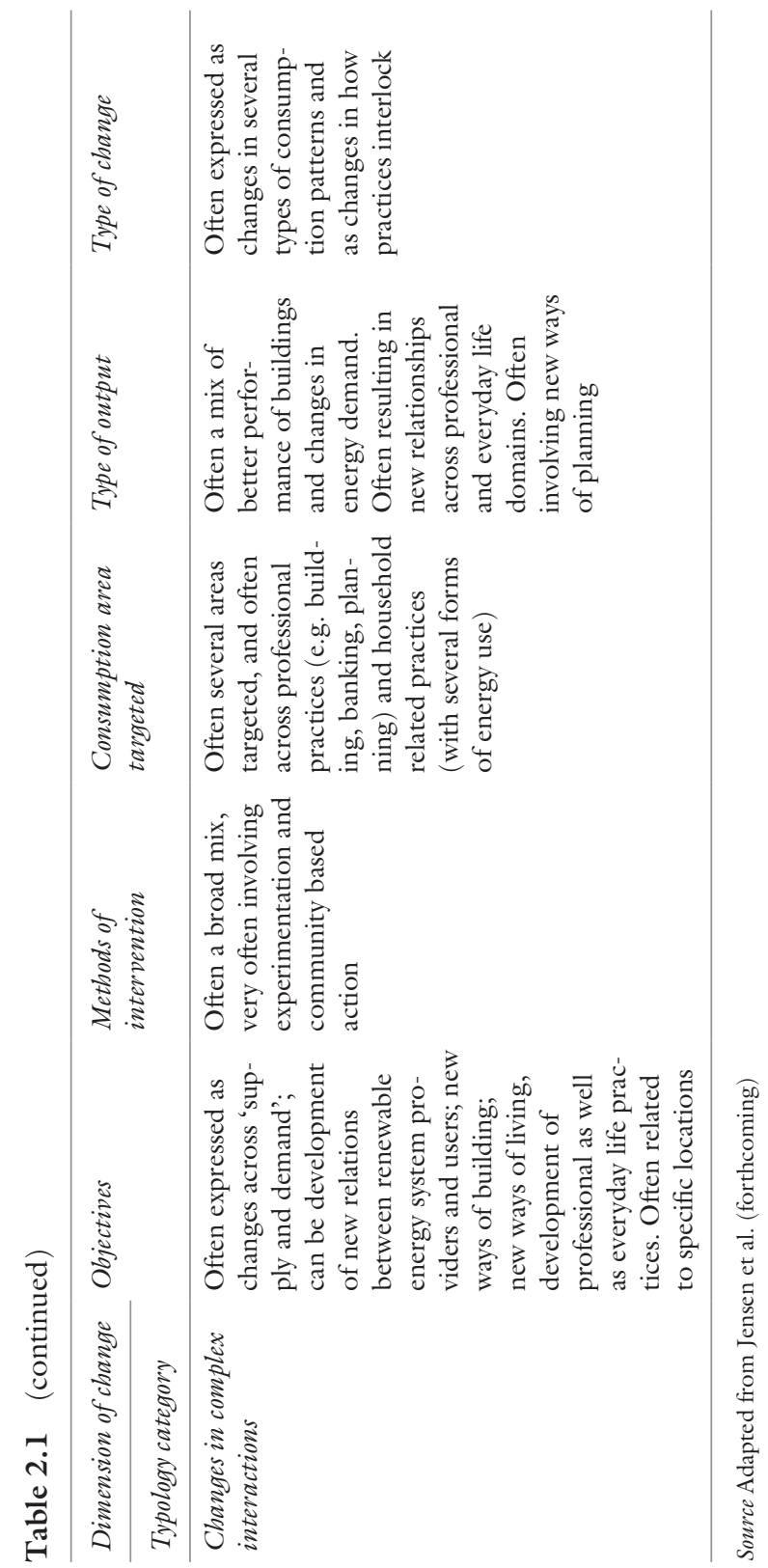


Table 2.1 provides an overview which can provide a guide or insight into what type of outputs might result from particular types of objectives, and related methods of intervention.

\section{ENERGISE REVIEW of 1000+SECIs CATEgorised According to the Problem Framing Typology}

The ENERGISE review of 1000+European SECIs has resulted in an overview of the share of SECIs that are underpinned by each of the four typology categories presented above. ${ }^{2}$ At least $75 \%$ of the SECIs are underpinned by common energy problem framings, whereas less than $25 \%$ of SECIs seem underpinned by problem framings that challenge underlying dynamics of (and reasons for) energy demand. Interestingly, SECIs underpinned by alternative energy problem framings are also primarily small-scale and local, reaching far less people and actors than SECIs underpinned by classic energy problem framings. This is problematic, as current energy problem framings tend to prioritise (abstract) efficiency strategies, which may (1) obscure longer-term trends in demand and societal shifts in what energy is for and (2) reproduce specific, potentially unsustainable, understandings of 'service', including perceived standards for comfort and convenience (Shove 2017) (Table 2.2).

Drawing on the results of this extensive European review, each of the following chapters in this collection concludes by showcasing a good practice example of a European sustainable energy consumption initiative underpinned by alternative problem framings that take either everyday life situations or broader systemic complex interactions between several practices and systems to be the target of intervention. The case studies are practical 'real world' examples which are intended to serve as inspiration for anyone who would like to know more about how initiatives underpinned by alternative problem framings can be designed and operationalised.

\footnotetext{
${ }^{2}$ For more information about the ENERGISE review and classification of SECIs, please consult Jensen et al. (2018) and Jensen et al. (2017).
} 
Table 2.2 Overview of ENERGISE classification of SECIs

\begin{tabular}{|c|c|c|c|c|}
\hline & No. of initiatives & $\begin{array}{l}\% \text { of total } \\
\text { initiatives }\end{array}$ & $\begin{array}{l}\text { Sub-national } \\
\text { (e.g. local; } \\
\text { regional) }\end{array}$ & $\begin{array}{l}\text { Nationall } \\
\text { cross-national }\end{array}$ \\
\hline $\begin{array}{l}\text { Sustainable } \\
\text { energy } \\
\text { consumption } \\
\text { initiatives } \\
\text { (SECIs) - total }\end{array}$ & 1067 & 100 & 398 & 669 \\
\hline $\begin{array}{l}\text { Changes in } \\
\text { technology }\end{array}$ & 284 & 26.6 & 101 & 183 \\
\hline $\begin{array}{l}\text { Changes in indi- } \\
\text { vidual behaviour }\end{array}$ & 513 & 48 & 153 & 360 \\
\hline $\begin{array}{l}\text { Changes in } \\
\text { everyday life } \\
\text { situations }\end{array}$ & 123 & 11.5 & 56 & 67 \\
\hline $\begin{array}{l}\text { Changes } \\
\text { in complex } \\
\text { interactions }\end{array}$ & 147 & 13.8 & 88 & 59 \\
\hline
\end{tabular}

\section{REFERENCES}

Bjørn, A., Hauschild, M., Kabins, S., Jensen, C., Schmidt, J., \& Birkved, M., et al. (2018). Pursuing necessary reductions in embedded GHG emissions of developed economies: Will efficiency improvements and changes in consumption get us there? Global Environmental Change, 52, 314-324.

Christensen, T., Godskesen, M., Gram-Hanssen, K., Quitzau, M., \& Røpke, I. (2007). Greening the Danes: Experience with consumption and environment policies. Journal of Consumer Policy, 30, 91-116.

Genus, A., Fahy, F., Goggins, G., Iskandarova, M., \& Laakso, S. (2018). Imaginaries and practices: Learning from 'ENERGISE' about the integration of social sciences with the EU Energy Union. In Advancing energy policy (pp. 131-144). Cham: Palgrave Pivot.

Jensen, C., Goggins, G., \& Fahy, F. (2017). Construction of typologies of sustainable energy consumption initiatives. ENERGISE-European Network for Research, Good Practice and Innovation for Sustainable Energy, D2.4.

Jensen, C., Goggins, G., Fahy, F., Grealis, E., Vadovics, E., Genus, A., et al. (2018). Towards a practice-theoretical classification of sustainable energy consumption initiatives: Insights from social scientific energy research in 30 European countries. Energy Research and Social Science, 45, 297-306. 
Jensen, C., Goggins, G., Røpke, I., \& Fahy, F. (forthcoming). Achieving sustainability transitions in residential energy consumption across Europe: Do problem framings within existing initiatives match current and future needs?

Labanca, N., \& Bertoldi, P. (2018). Beyond energy efficiency and individual behaviours: Policy insights from social practice theories. Energy Policy, 115, 494-502.

Sahakian, M., Naef, P., Jensen, C., Goggins, G., \& Fahy, F. (2019). Challenging conventions towards energy sufficiency: Ruptures in laundry and heating routines in Europe. In ECEEE Summer Study 2019 Proceedings.

Sedlacko, M., Martinuzzi, A., Røpke, I., Videira, N., \& Antunes, P. (2014). Participatory systems mapping for sustainable consumption: Discussion of a method promoting systemic insights. Ecological Economics, 106, 33-43.

Shove, E. (2010). Beyond the ABC: Climate change policy and theories of social change. Journal of Environment and Planning, 42, 1273-1285.

Shove, E. (2017). What is wrong with energy efficiency? Building Research \& Information, 46, 1-11.

Shove, E., \& Walker, G. (2014). What is energy for? Social practice and energy demand. Theory, Culture and Society, 31(5), 41-58.

Southerton, D., \& Welch, D. (2018). Transitions for sustainable consumption after the Paris agreement. The Stanley Foundation. Available at https://www. stanleyfoundation.org/publications/pab/SustainableConsPAB1118.pdf.

Spurling, N., McMeekin, A., Shove, E., Southerton, D., \& Welch, D. (2013). Interventions in practice: Re-framing policy approaches to consumer behaviour. Sustainable Practices Research Group. Available at http://eprints.lancs. ac.uk/85608/.

Open Access This chapter is licensed under the terms of the Creative Commons Attribution 4.0 International License (http://creativecommons.org/licenses/ by $/ 4.0 /$ ), which permits use, sharing, adaptation, distribution and reproduction in any medium or format, as long as you give appropriate credit to the original author(s) and the source, provide a link to the Creative Commons license and indicate if changes were made.

The images or other third party material in this chapter are included in the chapter's Creative Commons license, unless indicated otherwise in a credit line to the material. If material is not included in the chapter's Creative Commons license and your intended use is not permitted by statutory regulation or exceeds the permitted use, you will need to obtain permission directly from the copyright holder.

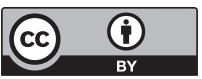

